\title{
An Evaluation of the Effect of Financial Literacy Education on Financial Literacy among College Students
}

\author{
Nesrin Akca, PhD \\ Department of Health Management, \\ Faculty of Health Sciences \\ Kırıkkale University, Turkey \\ Seda Sönmez, Msc \\ Department of Health Management \\ Faculty of Health Sciences \\ Kırıkkale University, Turkey \\ Tolga Şener, Msc \\ Medical Documentation and Secretarial Program \\ Vocational School of Health Services \\ Kırıkkale University, Turkey \\ Candoğan Akca, Msc \\ Medical Documentation and Secretarial Program \\ Vocational School of Health Services \\ Kirıkkale University, Turkey
}

\begin{abstract}
The aim of this research is to evaluate the effect of financial literacy education on financial literacy among college students, and to determine the financial literacy level of college students, and to explore whether individual characteristics have an effect on financial literacy level. 149 students, who have been receiving education in the state university vocational school, were hereby included into this research, and students were split into two categories randomly. No statistically-meaningful difference has been found between these two groups with regard to gender difference and age disparity $(p>0,05)$. One of these group had been receiving training with regard to financial literacy for two (2) weeks. After such training process, Financial Literacy Scale had been applied to both groups. As a result of analysis applied thereof, it was determined that all students attended to financial literacy education had intermediate level of financial literacy $(52,17 \pm 17,67)$, and financial literacy education had an effect on financial literacy $(p<0,05)$. Besides this, it was also determined that gender, class, the usage of internet banking and fathers' education level had significant effects on financial literacy $(p<0,05)$.
\end{abstract}

Keywords: Financial Literacy, Financial Literacy Education, College Students

\section{Introduction}

The need for financial education had been gradually increased by reason of the rapid developments that had been experienced for the creation and marketing of financial instruments, making it easier to access to the credit instruments, and the countries' tendencies for giving more responsibilities to the individuals, particularly for individual annuity insurance (Marcolin and Abraham, 2006:2). Through the lack of financial literacy, difficulties may be experienced while making long-term financial decisions, such as purchasing new houses, receiving more advanced education, or making retirement plans, and it may cause financial crises for the individuals and their family members (Braunstein ve Welch, 2002: 445). When it has been evaluated in macro-economic levels, lowlevel of financial literacy may sustain damages to the financial markets (e.g. reluctance to sell the stocks while depreciating) (Mandell, 2006:3). 
The term of financial literacy was brought to various countries' political agenda after experiencing the economic crises in 2008, and the significance of measuring individuals' financial literacy has been increased (The Organisation for Economic Co-operation and Development (OECD), 2016: 15). There are many definitions for the term of "Financial Literacy". But however, that, the most frequently used term definition is "the ability to use knowledge and competence in order for the efficient management of financial resources in life-long financial soundness" (Hung, and et.al., 2009:3). Even though different definitions of financial literacy could be found, the basic characteristics of financial literacy could be summarized as follows: (1) having knowledge and being educated with regard to money, assets, banking account, investment, credit, insurance and tax, (2) to understand the basic terms under the scope of money and asset management, and (3) to use such information while making and performing financial plans (Hogarth, 2002; 15-16).

It has been stated that people could manage their assets more properly thanks to the improvement of financial literacy, and they thus could take the right decisions with regard to important matters, such as, education, health and retirement plan (Cole and Fernando, 2008:2). Financial literacy education is the most-used tools to improve the financial literacy (Hastings, et.al., 2013:349). Financial literacy education comprises of the main financial terms and information taught for the improvement of any individual's financial literacy (Blue et.al., 2014:4). With the financial literacy education, it is aimed to transform individuals into strengthened market actors by enabling them to display responsible financial actions in order to increase their prosperity (Willis, 2008: 1-2). In particular, since important and grafted financial decisions has to be made at early ages, and making financial mistakes in future may create more economic and financial costs, such circumstances have increased the importance of financial literacy research to be applied to rising generation (Lusardi, et.al., 2010:359). It was determined as per the previous researches in literature that rising generation didn't find themselves adequate while taking significant financial decisions, and in general, the financial literacy ratio was low, and thus rising generation took wrong decisions for financial matters (Lusardi, et.al. 2010: 365; Chen and Volpe, 1998: 122; Jorgensen, 2007: 43).

In this research, the study to determine the financial literacy ratio among the college students was performed, since it has been asserted that information to be received at early ages could affect the future financial decisions. The aim of this research is to determine the participants' financial literacy level, and to conclude whether the financial literacy education have an effect on financial literacy. So, this research was performed in order to determine whether the low-level of financial literacy could be improved through the submission of financial literacy education. Also, which personal characteristics have an effect on college students' financial literacy level.

\section{Methodology}

The aim of this research is to evaluate the effect of financial literacy education on financial literacy among college students, and to determine the financial literacy level of college students, and to explore whether individual characteristics have an effect on financial literacy level. Since there is limited number of studies carried out for the determination of the effect of financial literacy education on financial literacy, such circumstance increases the importance of this study.

The working group of this study, which was carried out between March 2017 - June 2017, was comprises of 149 college students from a state university vocation school. Having received no financial literacy education, and being volunteer were determined as the prerequisite to attend this research. These students selected for this research were split into two categories randomly, and no statistically-meaningful difference has been found between these two groups with regard to gender difference $\left(\chi^{2}=2,274 ; p=0,192\right)$ and age disparity $\left(\chi^{2}=2,481\right.$; $\mathrm{p}=0,148)(\mathrm{p}>0,05)$. One of these group (training group) had been receiving training with regard to financial literacy for two (2) weeks and the other group (control group) didn't have any training. Within the scope of financial literacy education, the term of financial literacy, basis concepts with regard to finance, accounting and economy, financial planning, time-value of money, individual banking, retirement, insurance business, the reading and understanding of financial statements, financial markets, investment decisions and investment plans, tax and applicable legislation, investment tools, math and interest calculations, setting up budget, etc. had been lectured to the students. At the end of two (2) months, the survey form used as data collection tool was applied to both groups. The survey form used for this research contains of two categories, one of which focuses on personal characteristics, and the other focuses on financial literacy. "Financial Literacy Scale" developed by Kılıç and et.al (2015) was used to measure the financial literacy level of the students. 
This scale contains thirty-eight (38) questions, ranging from basic economy and finance, individual banking, retirement and insurance, financial statements, investment, tax and legislation, math and interest calculations and finance agenda. One (1) point was appointed for each correct answer and more scores indicate more knowledge on financial literacy. All data obtained from this research was evaluated with the SPSS 25.0 package program in an attempt to use such date in line with the research objective.

Firstly, the compliance study for normal distribution had been carried out, and parametric tests had been used for the cases, where normal distribution was observed $(\mathrm{z}=0,066 ; \mathrm{p}=0,200)$ and the observation number was higher than 30; and non-parametric tests had been used for the cases where such number was lower than 30, and MannWhitney $\mathrm{U}$ test and two sample $\mathrm{t}$ test had been used for the analysis.

\section{Results}

Table 1. Descriptive statistics for training group $(n=74)$

\begin{tabular}{|l|c|c|}
\hline Characteristics & Frequency & Percentage (\%) \\
\hline Gender & 25 & 33,80 \\
Female & 49 & 66,20 \\
Male & 17 & 23,00 \\
\hline Age Groups & 57 & 77,00 \\
\hline Under 20 years & 19 & 25,70 \\
20 years and over & 55 & 74,30 \\
\hline Class & & 50,00 \\
1.Grade & 37 & 50,00 \\
2.Grade & 37 & 56,80 \\
\hline Credit Card Usage & & 43,20 \\
\hline Yes & 42 & 10,80 \\
No & 32 & 89,20 \\
\hline Internet Banking Instrument Usage & & \\
\hline Yes & 8 & 56,80 \\
No & 66 & 43,20 \\
\hline Retirement Plan Usage & & 87,80 \\
\hline Yes & 42 & 12,20 \\
\hline No & 32 & \\
\hline Education Status of Father & 65 & \\
\hline Primary school or lower & 9 & \\
High school and over & & \\
\hline Education Status of Mother & & \\
\hline Primary school or lower & & \\
High school and over & & \\
\hline
\end{tabular}

In Table1, descriptive statistics related to the group, which had received financial literacy education, were indicated. It was observed after the evaluation of table-1 that the majority of the participants were male $(66.2 \%)$, and 20 years and over (\%77.0), and (74.3\%) were in $2^{\text {nd }}$ grade. More than half of the students use internet banking instruments $(56,8 \%)$, and most of them $(89,2 \%)$ have no retirement plan. It was also observed that the education status of most of the students' mother and father were primary school or lower degree (respectively, 56,8\%, and $87,8 \%)$. 
Table 2. Descriptive statistics for control group $(n=75)$

\begin{tabular}{|l|c|c|}
\hline Characteristics & Frequency & Percentage (\%) \\
\hline Gender & 17 & 22,70 \\
Female & 58 & 77,30 \\
Male & 26 & 34,70 \\
\hline Age Groups & 49 & 65,30 \\
\hline Under 20 years & 40 & 53,30 \\
20 years and over & 35 & 46,70 \\
\hline Class & & 40,00 \\
1.Grade & 30 & 60,00 \\
2.Grade & 45 & 40,00 \\
\hline Credit Card Usage & 30 & 60,00 \\
\hline Yes & 45 & 2,70 \\
No & & 97,30 \\
\hline Internet Banking Instrument Usage & 2 & 57,30 \\
Yes & 73 & 42,70 \\
\hline No & & \\
\hline Retirement Plan Usage & 43 & 80,00 \\
Yes & 32 & 20,00 \\
\hline No & & \\
\hline Education Status of Father & 60 & \\
\hline Primary school or lower & 15 & \\
\hline High school and over & & \\
\hline Pducation Status of Mother & & \\
High school and over & & \\
\hline
\end{tabular}

In Table 2, descriptive statistics related to the group, which hadn't received financial literacy education, were indicated. It was observed after the evaluation of table-2 that the majority of the participants were male (77.3\%), and over 20 years $(65.3 \%)$, and $(53.3 \%)$ were in $1^{\text {st }}$ grade. Most of the students do not use internet banking $(60,0 \%)$ and credit card instruments $(60,0 \%)$, and most of them $(97,3 \%)$ have no retirement plan. It was also observed that the education status of most of the students' mother and father were primary school or lower degree (respectively, 57,3\%, and 80,0\%).

Table 3. Financial literacy levels of the students

\begin{tabular}{|c|c|c|c|c|c|}
\hline $\begin{array}{l}\text { Financial Literacy } \\
\text { Dimensions }\end{array}$ & Groups & Minimum & Maximum & Means & $\begin{array}{l}\text { Standard } \\
\text { Deviation }\end{array}$ \\
\hline \multirow[t]{3}{*}{ Basic economy and finance } & Training & 12,50 & 100,00 & 56,42 & 21,22 \\
\hline & Control & 0,00 & 87,50 & 34,33 & 22,98 \\
\hline & Total & 0,00 & 100,00 & 45,30 & 24,68 \\
\hline \multirow[t]{3}{*}{ Individual banking } & Training & 16,67 & 100,00 & 69,37 & 20,28 \\
\hline & Control & 0,00 & 100,00 & 55,33 & 22,95 \\
\hline & Total & 0,00 & 100,00 & 62,30 & 22,71 \\
\hline \multirow[t]{3}{*}{ Retirement and insurance } & Training & 0,00 & 100,00 & 73,78 & 23,85 \\
\hline & Control & 0,00 & 100,00 & 62,40 & 23,47 \\
\hline & Total & 0,00 & 100,00 & 68,05 & 24,26 \\
\hline \multirow[t]{3}{*}{ Financial statements } & Training & 0,00 & 100,00 & 61,82 & 27,83 \\
\hline & Control & 0,00 & 100,00 & 39,66 & 30,23 \\
\hline & Total & 0,00 & 100,00 & 50,67 & 31,02 \\
\hline \multirow[t]{3}{*}{ Investment } & Training & 0,00 & 100,00 & 42,16 & 23,07 \\
\hline & Control & 0,00 & 80,00 & 27,20 & 20,44 \\
\hline & Total & 0,00 & 100,00 & 34,63 & 22,97 \\
\hline \multirow[t]{3}{*}{ Tax and legislation } & Training & 20,00 & 100,00 & 69,19 & 21,75 \\
\hline & Control & 0,00 & 100,00 & 51,20 & 23,07 \\
\hline & Total & 0,00 & 100,00 & 60,13 & 24,10 \\
\hline \multirow{3}{*}{$\begin{array}{l}\text { Math and interest } \\
\text { calculations }\end{array}$} & Training & 0,00 & 100,00 & 61,89 & 26,92 \\
\hline & Control & 0,00 & 80,00 & 30,13 & 22,87 \\
\hline & Total & 0,00 & 100,00 & 45,90 & 29,54 \\
\hline \multirow[t]{3}{*}{ Finance agenda } & Training & 0,00 & 100,00 & 61,93 & 25,51 \\
\hline & Control & 0,00 & 83,33 & 42,44 & 22,31 \\
\hline & Total & 0,00 & 100,00 & 52,12 & 25,79 \\
\hline \multirow[t]{3}{*}{ Total score } & Training & 23,68 & 89,47 & 61,84 & 15,51 \\
\hline & Control & 23,68 & 89,47 & 42,63 & 14,19 \\
\hline & Total & 2,63 & 89,47 & 52,17 & 17,67 \\
\hline
\end{tabular}


In Table 3, descriptive statistics related to the students' general financial literacy level had been indicated. Because of unequal number of question mentioned in each category, scores obtained from such categories had been standardized (0-100).

It was observed while evaluating the table-3 that financial literacy level between the students received financial literacy education was $61,84 \pm 15,51$, the financial literacy level between the students haven't received financial literacy education was $42,63 \pm 14,19$, and general financial literacy level was $52,17 \pm 17,67$. Besides this, the part for which highest financial literacy level was observed for the students, whom received/haven't financial literacy education, and for all students, was retirement and insurance business (respectively 73,78 $\pm 23,85,62,40 \pm 23,47$, $68,05 \pm 24,26$ ) and lowest level was observed for investment (respectively 42,16 $\pm 23,07,27,20 \pm 20,44$, $34,63 \pm 22,97)$.

Table 4. Effect of financial literacy education on financial literacy levels

\begin{tabular}{|c|c|c|c|c|c|}
\hline Financial Literacy Dimensions & Groups & Means & $\begin{array}{l}\text { Standard } \\
\text { Deviation }\end{array}$ & $\mathbf{t}$ & $\mathbf{p}^{*}$ \\
\hline \multirow[t]{2}{*}{ Basic economy and finance } & Training & 56,42 & 21,22 & \multirow[t]{2}{*}{6,091} & \multirow[t]{2}{*}{$<0,0001$} \\
\hline & Control & 34,33 & 22,98 & & \\
\hline \multirow[t]{2}{*}{ Individual banking } & Training & 69,37 & 20,28 & \multirow[t]{2}{*}{3,954} & \multirow[t]{2}{*}{$<0,0001$} \\
\hline & Control & 55,33 & 22,95 & & \\
\hline \multirow[t]{2}{*}{ Retirement and insurance } & Training & 73,78 & 23,85 & \multirow[t]{2}{*}{2,936} & \multirow[t]{2}{*}{0,004} \\
\hline & Control & 62,40 & 23,47 & & \\
\hline \multirow{2}{*}{ Financial statements } & Training & 61,82 & 27,83 & \multirow[t]{2}{*}{4,653} & \multirow[t]{2}{*}{$<0,0001$} \\
\hline & Control & 39,66 & 30,23 & & \\
\hline \multirow[t]{2}{*}{ Investment } & Training & 42,16 & 23,07 & \multirow[t]{2}{*}{4,192} & \multirow[t]{2}{*}{$<0,0001$} \\
\hline & Control & 27,20 & 20,44 & & \\
\hline \multirow[t]{2}{*}{ Tax and legislation } & Training & 69,19 & 21,75 & \multirow[t]{2}{*}{4,895} & \multirow[t]{2}{*}{$<0,0001$} \\
\hline & Control & 51,20 & 23,07 & & \\
\hline \multirow[t]{2}{*}{ Math and interest calculations } & Training & 61,89 & 26,92 & \multirow[t]{2}{*}{7,763} & \multirow[t]{2}{*}{$<0,0001$} \\
\hline & Control & 30,13 & 22,87 & & \\
\hline \multirow[t]{2}{*}{ Finance agenda } & Training & 61,93 & 25,51 & \multirow[t]{2}{*}{4,967} & \multirow[t]{2}{*}{$<0,0001$} \\
\hline & Control & 42,44 & 22,31 & & \\
\hline \multirow[t]{2}{*}{ Total score } & Training & 61,84 & 15,51 & \multirow[t]{2}{*}{7,889} & \multirow[t]{2}{*}{$<0,0001$} \\
\hline & Control & 42,63 & 14,19 & & \\
\hline
\end{tabular}

*: $\mathrm{p}<0,05$ significance

In Table 4, it was evaluated whether there is any difference between the students that had financial literacy education, and the students hadn't had financial literacy education. It was observed that students that had financial literacy education had higher financial literacy level compared to the ones hadn't received such training, and the difference between these two groups was found as statistically-meaningful ( $p<0,05)$.

Table 5. Evaluation of financial literacy levels by individual characteristics



*: $\mathrm{p}<0,05$ significance 
In Table 5, the evaluations performed according to the students' personal characteristics, which affect the level of financial literacy among the college students, were indicated. As the table examined in detail, statisticallymeaningful difference was found for individual banking category according to the personal characteristics $(\mathrm{t}=2,586 ; \mathrm{p}=0,011)$, and for tax and legislation $(\mathrm{t}=2,312 ; \mathrm{p}=0,022)$, and financial literacy total score $(\mathrm{t}=2,138$; $\mathrm{p}=0,034)$ according to class variables. As per those findings, it was determined that girls and $2^{\text {nd }}$ grade students had more financial literacy level than respectively boys and $1^{\text {st }}$ grade students. No statistically meaningful difference had been found in terms of age groups $(\mathrm{p}>0,05)$.

Table 6. Evaluation of financial literacy levels by individual financial characteristics

\begin{tabular}{|c|c|c|c|c|c|c|}
\hline \multirow{2}{*}{ Financial Literacy Dimensions } & \multicolumn{2}{|c|}{ Credit Card Usage } & \multicolumn{2}{|c|}{ Internet Banking Usage } & \multicolumn{2}{|c|}{ Retirement Plan Usage* } \\
\hline & Yes & No & Yes & No & Yes & No \\
\hline \multirow{2}{*}{ Basic economy and finance } & $48,32 \pm 25,36$ & $42,83 \pm 23,98$ & $49,82 \pm 23,31$ & $41,07 \pm 25,31$ & $50,00 \pm 16,45$ & $50,00 \pm 25,13$ \\
\hline & \multicolumn{2}{|c|}{$\mathrm{t}=1,353 \quad \mathrm{p}=0,178$} & \multicolumn{2}{|c|}{$\mathrm{t}=2,191 \quad \mathbf{p}=\mathbf{0 , 0 3 0} * *$} & \multicolumn{2}{|c|}{$\mathrm{u}=566,0 \quad \mathrm{p}=0,322$} \\
\hline \multirow{2}{*}{ Individual banking } & $64,67 \pm 22,00$ & $60,36 \pm 23,22$ & $63,89 \pm 21,30$ & $60,82 \pm 23,99$ & $75,00 \pm 21,44$ & $66,67 \pm 22,81$ \\
\hline & \multicolumn{2}{|c|}{$\mathrm{t}=1,154 \quad \mathrm{p}=0,250$} & \multicolumn{2}{|c|}{$\mathrm{t}=0,823 \quad \mathrm{p}=0,412$} & \multicolumn{2}{|c|}{$\mathrm{u}=590,5 \quad \mathrm{p}=0,416$} \\
\hline \multirow{2}{*}{ Retirement and insurance } & $68,36 \pm 25,38$ & $67,80 \pm 23,46$ & $70,00 \pm 23,01$ & $66,24 \pm 25,39$ & $80,00 \pm 15,77$ & $60,00 \pm 24,70$ \\
\hline & \multicolumn{2}{|c|}{$\mathrm{t}=0,138 \quad \mathrm{p}=0,890$} & \multicolumn{2}{|c|}{$\mathrm{t}=0,946 \quad \mathrm{p}=0,345$} & \multicolumn{2}{|c|}{$\mathrm{u}=567,0 \quad \mathrm{p}=0,314$} \\
\hline \multirow{2}{*}{ Financial statements } & $51,49 \pm 32,24$ & $50,00 \pm 30,17$ & $51,04 \pm 30,67$ & $50,32 \pm 31,54$ & $62,50 \pm 31,18$ & $50,00 \pm 31,12$ \\
\hline & \multicolumn{2}{|c|}{$\mathrm{t}=0,291 \quad \mathrm{p}=0,771$} & \multicolumn{2}{|l|}{$\mathrm{t}=0,141$} & \multicolumn{2}{|c|}{$\mathrm{u}=684,0 \quad \mathrm{p}=0,089$} \\
\hline \multirow{2}{*}{ Investment } & $33,73 \pm 22,88$ & $35,36 \pm 23,15$ & $33,89 \pm 22,67$ & $35,32 \pm 23,37$ & $20,00 \pm 16,99$ & $40,00 \pm 23,35$ \\
\hline & \multicolumn{2}{|c|}{$\mathrm{t}=-0,431 \quad \mathrm{p}=0,667$} & \multicolumn{2}{|c|}{$\mathrm{t}=-0,380 \quad \mathrm{p}=0,704$} & \multicolumn{2}{|c|}{$\mathrm{u}=602,5 \quad \mathrm{p}=0,469$} \\
\hline \multirow{2}{*}{ Tax and legislation } & $62,98 \pm 23,42$ & $57,80 \pm 24,54$ & $63,33 \pm 24,67$ & $57,14 \pm 23,33$ & $60,00 \pm 23,19$ & $60,00 \pm 24,19$ \\
\hline & \multicolumn{2}{|c|}{$\mathrm{t}=1,308 \quad \mathrm{p}=0,193$} & \multicolumn{2}{|c|}{$\mathrm{t}=1,574 \quad \mathrm{p}=0,118$} & \multicolumn{2}{|l|}{$\mathrm{u}=615,5$} \\
\hline \multirow{2}{*}{ Math and interest calculations } & $47,46 \pm 30,32$ & $44,63 \pm 29,02$ & $48,61 \pm 28,45$ & $43,37 \pm 30,50$ & $40,00 \pm 30,98$ & $40,00 \pm 29,55$ \\
\hline & \multicolumn{2}{|c|}{$\mathrm{t}=0,580 \quad \mathrm{p}=0,563$} & \multicolumn{2}{|c|}{$\mathrm{t}=1,081 \quad \mathrm{p}=0,281$} & \multicolumn{2}{|c|}{$\mathrm{u}=673,5 \quad \mathrm{p}=0,868$} \\
\hline \multirow{2}{*}{ Finance agenda } & $53,73 \pm 25,59$ & $50,81 \pm 26,04$ & $54,86 \pm 25,24$ & $49,56 \pm 26,20$ & $58,33 \pm 26,11$ & $50,00 \pm 25,73$ \\
\hline & \multicolumn{2}{|c|}{$\mathrm{t}=0,686 \quad \mathrm{p}=0,494$} & \multicolumn{2}{|c|}{$\mathrm{t}=1,254 \quad \mathrm{p}=0,212$} & \multicolumn{2}{|c|}{$\mathrm{u}=550,0 \quad \mathrm{p}=0,263$} \\
\hline & $53,77 \pm 18,29$ & $50,86 \pm 17,14$ & $54,35 \pm 17,02$ & $50,13 \pm 18,13$ & $52,63 \pm 12,67$ & $52,63 \pm 17,98$ \\
\hline & $\mathrm{t}=0,998$ & 0,320 & $\mathrm{t}=1,460$ & $\mathrm{p}=0,146$ & $\mathrm{u}=613,0$ & $\mathrm{p}=0,533$ \\
\hline
\end{tabular}

*: The median was used as a measure of central tendency because the number of observations in one of the groups in the variable of retirement plan usage is less than 30 .

**: $p<0,05$ significance

In Table 6, college students' financial literacy had been compered according to certain personal characteristics. When we evaluated the table 6 , only the variable of internet banking usage causes statistically-meaningful difference in terms of financial literacy in the categories of basic economy and finance $(\mathrm{t}=2,191 ; \mathrm{p}=0,030)$. According to those findings, it was determined that students, who use internet banking had lower level of financial literacy than those students, who don't use internet banking. No statistically-meaningful difference had been found between the variables of credit card usage and retirement plan usage ( $p>0,05)$.

Table 7. Evaluation of financial literacy levels by education status of parents

\begin{tabular}{|c|c|c|c|c|}
\hline \multirow[t]{2}{*}{ Financial Literacy Dimensions } & \multicolumn{2}{|c|}{ Education Status of Mother* } & \multicolumn{2}{|c|}{ Education Status of Father* } \\
\hline & $\begin{array}{c}\text { Primary or lower } \\
\text { level }\end{array}$ & $\begin{array}{c}\text { High-school or upper } \\
\text { level }\end{array}$ & $\begin{array}{c}\text { Primary or lower } \\
\text { level }\end{array}$ & \begin{tabular}{|c|}
$\begin{array}{c}\text { High-school or upper } \\
\text { level }\end{array}$ \\
\end{tabular} \\
\hline \multirow{2}{*}{ Basic economy and finance } & $50,00 \pm 25,08$ & $50,00 \pm 21,90$ & $37,50 \pm 25,48$ & $50,00 \pm 22,81$ \\
\hline & \multicolumn{2}{|c|}{$\begin{array}{l}150,00 \pm 21,90 \\
\mathrm{p}=0,224\end{array}$} & \multicolumn{2}{|c|}{$\mathbf{p}=\mathbf{0 , 0 2 6} * *$} \\
\hline \multirow[t]{2}{*}{ Individual banking } & $66,67 \pm 23,11$ & $58,33 \pm 20,25$ & $66,67 \pm 21,47$ & $66,67 \pm 24,28$ \\
\hline & \multicolumn{2}{|l|}{$\begin{array}{l}66,67 \pm 23,11 \\
u=1262,5\end{array}$} & \multicolumn{2}{|l|}{$\mathrm{u}=2404,0$} \\
\hline \multirow[t]{2}{*}{ Retirement and insurance } & $60,00 \pm 25,05$ & $80,00 \pm 19,26$ & $60,00 \pm 23,58$ & $80,00 \pm 25,19$ \\
\hline & $\mathrm{u}=1288,0$ & $\mathrm{p}=0,256$ & \multicolumn{2}{|l|}{$\mathrm{u}=2427,5$} \\
\hline \multirow[t]{2}{*}{ Financial statements } & $50,00 \pm 31,42$ & $50,00 \pm 29,48$ & $50,00 \pm 32,38$ & $50,00 \pm 29,35$ \\
\hline & $\mathrm{u}=1494,5$ & $\mathrm{p}=0,977$ & \multicolumn{2}{|l|}{$\mathrm{u}=2668,0$} \\
\hline \multirow[t]{2}{*}{ Investment } & $40,00 \pm 23,09$ & $30,00 \pm 22,70$ & $40,00 \pm 22,38$ & $40,00 \pm 23,90$ \\
\hline & $\mathrm{u}=1413,5$ & $\mathrm{p}=0,645$ & \multicolumn{2}{|l|}{$\mathrm{u}=2670,5$} \\
\hline \multirow[t]{2}{*}{ Tax and legislation } & $60,00 \pm 24,69$ & $60,00 \pm 21,19$ & $60,00 \pm 23,90$ & $60,00 \pm 24,56$ \\
\hline & \multicolumn{2}{|l|}{$\mathrm{u}=1452,0$} & \multicolumn{2}{|l|}{$\mathrm{u}=2596,5$} \\
\hline \multirow[t]{2}{*}{ Math and interest calculations } & $40,00 \pm 29,57$ & $40,00 \pm 29,87$ & $40,00 \pm 28,78$ & $40,00 \pm 30,63$ \\
\hline & $\mathrm{u}=1396,0$ & $\mathrm{p}=0,583$ & \multicolumn{2}{|l|}{$\mathrm{u}=2554,5$} \\
\hline \multirow[t]{2}{*}{ Finance agenda } & $50,00 \pm 25,38$ & $66,67 \pm 27,35$ & $50,00 \pm 25,24$ & $66,67 \pm 26,14$ \\
\hline & $\mathrm{u}=1235,0$ & $\mathrm{p}=0,164$ & \multicolumn{2}{|l|}{$\mathrm{u}=2252,5$} \\
\hline \multirow[t]{2}{*}{ Total score } & $52,63 \pm 18,19$ & $53,94 \pm 14,95$ & $50,00 \pm 17,73$ & $56,58 \pm 17,62$ \\
\hline & $\mathrm{u}=1448,0$ & $\mathrm{p}=0,788$ & \multicolumn{2}{|l|}{$\mathrm{u}=2428,5$} \\
\hline
\end{tabular}


*: The median was used as a measure of central tendency because the number of observations in one of the groups in the variables is less than 30 .

$* *: \mathrm{p}<0,05$ significance

In Table 7, college students' financial literacy had been compered according to certain personal characteristics. When we evaluated the table-7, only the variable of education status of father causes statistically-meaningful difference in terms of financial literacy in the categories of basic economy and finance $(t=2,147 ; p=0,026)$. According to those findings, it was determined that students, whose fathers had received high-school or upper level of education had higher financial literacy level than those, whose fathers had received primary or lower level of education. No statistically-meaningful difference had been found for the variables of education status of mother $(\mathrm{p}>0,05)$.

\section{Discussion}

In this study, the effects of financial literacy education on the financial literacy among the college students were evaluated, and the level of financial literacy were determined, and it was hereby assessed that whether personal characteristics had an effect on financial literacy.

According to the results yielded from herein, students that had financial literacy education had upper intermediate level of financial literacy $(61,84 \pm 15,51)$, and students that hadn't received financial literacy had pre-intermediate level of financial literacy $(42,63 \pm 14,19)$. It was also found that the categories, for which highest level of financial literacy was observed, was retirement plan and insurance business $(68,05 \pm 24,26)$; and lowest level of financial literacy was observed for investment $(34,63 \pm 22,97)$. It was determined within the research conducted by Barmaki and Şener (2017), who performed such research in order to evaluate financial literacy level of college students, it was revealed that students had intermediate level of financial literacy and had highest level of financial literacy for basic monetary concepts, and had lowest level of financial literacy for savings and investment plans. It was taught that students had relatively more information with regard to insurance business and retirement plan, because of the existence of insured or retired family members; and they had relatively low level of information with regard to investment plans, because there were young and they hadn't any income suitable for financial management. Furthermore, according to the research conducted by Lusardi and et.al., (2010) in order to determine the financial literacy level among young people, people had relatively low level of financial literacy, and the children's parents that make investment for retirement plans had higher financial literacy level that poorer parents. According to the results, in which the effects of financial literacy education on financial literacy were evaluated, it was determined that students that had financial literacy education had higher level of financial literacy in comparison to those, who hadn't received financial literacy education $(\mathrm{p}<0,05)$.

Furthermore, it was also stated that financial literacy education was one of the most-efficient tool for increasing the financial literacy level among the college students. According to the research conducted by Er and et.al. (2014) for the deliberation of the effects of field of education on financial literacy, students, who had received financial training had more financial literacy level than those, who hadn't received any financial training. And, in parallel with the foregoing circumstances, the research conducted by Bernheim and et.al (2001) revealed that persons that had received financial training in high-school tend to save more money at their medium ages.

And according to the research conducted by Biçer and Altan (2016) for the evaluation of attitude and behaviors of college students with regard to financial literacy, students that had financial training had more financial literacy perception than those who hadn't received financial literacy education. Furthermore, in the research conducted by Mandell and Hanson (2009) for the evaluation of the effect of financial literacy education on financial literacy level among the college and high-school students, it was determined that students attended to financial training had more financial literacy level. In this research, and upon the evaluation financial literacy based on personal characteristics, statistically-meaningful difference had been observed for gender, class, the usage of internet banking and fathers' education level $(\mathrm{p}<0,05)$, but however that, no statistically-meaningful difference had been found with regard to variables of age, credit card usage, individual retirement, and mother education level( $p>0,05)$. According to those findings, it was determined that girls had higher level of financial literacy than boys with regard to individual banking, and $2^{\text {nd }}$ grade students had higher level of financial literacy than $1^{\text {st }}$ grade students with regard to tax, applicable legislation and general concepts, and students use internet banking had higher level of financial literacy than those, who don't use such banking instruments with regard to basic finance and economy concepts, and students, whose fathers had received high-school or upper level of education had 
more financial literacy than those, whose fathers had received primary school or lower level of education. According to the research conducted by Chen and Volpe (2002) in an attempt to determine the effect of gender difference on financial literacy level, it was revealed that male students had more financial literacy level than girls. According to the research performed by Ergin and et.al. (2014) for the determination of financial literacy level among college students of business administration, it was revealed that students had fundamental level of financial literacy, and this level may be varied based on gender, teaching methods, and monthly average household income. Besides this, according to the research conducted by Cude and et.al. (2006) for the evaluation of financial literacy level of college students, it was expressed that parents were the most efficient factor for the socialization of students in terms of financial matters. And, according to the research conducted by Chen and Volpe (1998) with 924 college students, it was revealed that students' financial literacy level was intermediate, and women, low-class students, unemployed persons, and persons below the age of 30, and persons that had lack of required business experience had lower level of financial literacy. In addition to the foregoing, according to the research conducted by Jorgensen and Savla (2010), in which they evaluated the financial literacy among young persons, families had direct or medium level of effects on financial literacy. And as per the research conducted by Çoşkun (2016), in which the financial literacy level among the vocational school students was evaluated, personal characteristics (e.g., gender, marital status, department, class, program, household level of income, employment conditions, and residential address) have no effect on financial literacy. And pursuant to the research carried out by Temizel and Bayram (2011), in which the financial literacy level of 433 students, who had been receiving education at the faculty of economics and administrative business, were measured, it was revealed that $84 \%$ of the students received financial information from their parents.

In conclusion, it was revealed within the scope of this research that students' financial literacy ratio was intermediate level, financial literacy education had increased the level of financial literacy among the students, certain personal characteristics, namely gender, class, usage of internet banking and father education level had effects on financial literacy. According to these findings, it was suggested that inclusion on financial literacy education into the official curriculum so as to increase the financial literacy of college students could pave the way for students to take better financial decisions, and to increase their ability to make savings, and to provide opportunity to improve themselves in the field of financial investments. But however, that, there were certain limitations in terms of the generalization of the results obtained from this research, since it was conducted to the students, who had been receiving education at state university vocational school only.

Besides this, it was suggested that new researches should be carried out with regard to different characteristics and circumstances deemed to have effect on financial literacy. It was suggested that results obtained from this research shall provide contributions to the activities related to the improvement of financial literacy.

\section{References}

Barmaki, N., \& Şener, A. (2017). Financial Literacy Levels of University Students. Journal of Current Researches on Social Sciences, 7(3), 67-88.

Bernheim, B. D., Garrett, D. M., \& Maki, D. M. (2001). Education and saving:: The long-term effects of high school financial curriculum mandates. Journal of public Economics, 80(3), 435-465.

Biçer, E.B., \& Altan, F. (2016). Üniversite Öğrencilerinin Finansal Okuryazarlık ile İlgili Tutum ve Davranışlarının Değerlendirilmesi. Atatürk Üniversitesi Sosyal Bilimler Enstitüsü Dergisi, 20(4), 15011517.

Blue, L., Grootenboer, P., \& Brimble, M. (2014). Financial literacy education in the curriculum: Making the grade or missing the mark?. International Review of Economics Education, 16, 51-62.

Braunstein, S., \& Welch, C. (2002). Financial literacy: An overview of practice, research, and policy. Fed. Res. Bull., 88, 445-457.

Chen, H., \& Volpe, R. P. (1998). An analysis of personal financial literacy among college students. Financial services review, 7(2), 107-128.

Chen, H., \& Volpe, R. P. (2002). Gender differences in personal financial literacy among college students. Financial services review, 11(3), 289-307.

Cole, S., \& Fernando, N. (2008). Assessing the importance of financial literacy. ADB Finance for the Poor, 9(2), 1-6. 
Coşkun, S. (2016). Üniversite Öğrencilerinin Finansal Davranış Ve Tutumlarının Belirlenmesi: Finansal Okuryazarlık Algıları Üzerine Bir Araştırma. Insan ve Toplum Bilimleri Araştırmaları Dergisi, 5(7), 2247-2258.

Cude, B., Lawrence, F., Lyons, A., Metzger, K., LeJeune, E., Marks, L., \& Machtmes, K. (2006). College students and financial literacy: What they know and what we need to learn. Proceedings of the Eastern Family Economics and Resource Management Association, 102(9), 106-109.

Er, F., Temizel, F., Özdemir, A., \& Sönmez, H. (2014). Lisans eğitim programlarının finansal okuryazarlık düzeyine etkisinin araştırılmas1: Türkiye örneği. Anadolu Üniversitesi Sosyal Bilimler Dergisi, 14(4), 113-125.

Ergün, B., Şahin, A., \& Ergin, E. (2014). Finansal Okuryazarlık: İşletme Bölümü Öğrencileri Üzerine $\quad$ Bir Çalışma. Journal of International Social Research, 7(34), 847-864.

Hastings, J. S., Madrian, B. C., \& Skimmyhorn, W. L. (2013). Financial literacy, financial education, and economic outcomes. Annu Rev Econom, 1(5), 347-373.

Hogarth, J. M. (2002). Financial literary and family \& consumer scences. Journal of Family and Consumer Sciences, 94(1), 14-28.

Hung, A., Parker, A. M., \& Yoong, J. (2009). Defining and measuring financial literacy. RAND Corporation Publications Department, Working Papers, 708. doi: 10.2139/ssrn.1498674.

Jorgensen, B. L. (2007). Financial literacy of college students: Parental and peer influences (Doctoral dissertation, Virginia Tech).

Jorgensen, B. L., \& Savla, J. (2010). Financial literacy of young adults: The importance of parental socialization. Family Relations, 59(4), 465-478.

Kılıç, Y., Ata, H. A., \& Seyrek, İ. H. (2015). Finansal okuryazarlık: Üniversite öğrencilerine yönelik bir araştırma. Muhasebe ve Finansman Dergisi, (66), 129-150.

Lusardi, A., Mitchell, O. S., \& Curto, V. (2010). Financial literacy among the young. Journal of consumer affairs, 44(2), 358-380.

Mandell, L. (2006). Financial Literacy: If It's So Important, Why Isn't It Improving?. Networks Financial Institute Policy Brief No. 2006-PB-08. doi: https://dx.doi.org/10.2139/ssrn.923557

Mandell, L., \& Hanson, K. O. (2009, January). The impact of financial education in high school and college on financial literacy and subsequent financial decision making. In American Economic Association Meetings (Vol. 4, p. 2009).

Marcolin, S., \& Abraham, A. (2006). Financial literacy research: Current literature and future opportunities., In P. Basu, G. O'Neill \& A. Travaglione (Eds.), Proceedings of the 3rd International Conference on Contemporary Business, Leura NSW, 21-22 September 2006. Australia: Faculty of Commerce, Charles Stuart University.

OECD. (2016). OECD/INFE International Survey of Adult Financial Literacy Competencies. Available at:https://www.oecd.org/daf/fin/financial-education/OECD-INFE-International-Survey-of-AdultFinancial-Literacy-Competencies.pdf

Temizel, F., \& Bayram, F. (2011). Finansal okuryazarlık: Anadolu üniversitesi İktisadi İdari Bilimler Fakültesi (İ̈BF) öğrencilerine yönelik bir araştırma. CÜ İktisadi ve İdari Bilimler Dergisi, 12(1), 73-86.

Willis, L. E. (2008). Evidence and ideology in assessing the effectiveness of financial literacy education. Faculty Scholarship, 197, 1-25. 